\title{
At være eller ikke at være luthersk
}

\author{
Kætteri i en moderne kontekst
}

MARIE VEJRUP NIELSEN

\begin{abstract}
ENGLISH ABSTRACT: This article explores the formation of normative discourses in texts that utilise references to Luther or Lutheran in the Danish public debate. The article is based on a research project focusing on the development of such references in the two Danish newspapers, Jyllandsposten and Politiken, from 2000 to 2001. In continuation of the project, this article analyses references to Luther/Lutheran from the perspective of the construction of 'orthodox' and 'heretical' positions based on the reflections of Jacques Berlinerblau and Gerd Baumann on mechanisms of 'heresy' in relation to selfing/othering. The article argues that there is a process of a selfing/othering taking place in the material, as will be shown through the identification of three discourse packets with variations on the perception of the relationship between Luther/Lutheran and the values of Danish society today through the analysis of cases with references to Luther/Lutheran.
\end{abstract}

DANSK RESUMÉ: Denne artikel undersøger dannelsen af normative diskurser i tekster, der benytter henvisninger til Luther eller luthersk i den danske offentlige debat. Artiklen er baseret på et forskningsprojekt, der afdxkkede udviklingen $i$ sådanne henvisninger $i$ Jyllandsposten og Politiken fra 2000 til 2001. I forlængelse af projektet analyseres referencer til Luther/luthersk ud fra spørgsmålet om konstruktionen af 'ortodokse' og 'kættersk' positioner ud fra Jacques Berlinerblau og Gerd Baumanns overvejelser om dannelsen af forestillinger om egen identitet og andres identitet (en såkaldt selfing/ othering-proces)i en moderne kontekst. Artiklen argumenterer for, at der finder en selfing/othering-proces sted $i$ materialet ud fra identifikationen af tre diskurspakker der repræsenterer forskellige syn på sammenhængen mellem Luther/luthersk og værdier $i$ det danske samfund i dag gennem analysen af cases med referencer til Luther/luthersk.

Keywords: Heresy; Public debate; Luther/Lutheran, Danish cultural identity. 
Luther og det at være luthersk har i en årrække været en del af den danske offentlige debat i tilknytning til diskussioner om samfundets udvikling i et krydsfelt af temaer som religion, politik, identitet og kultur. Da Anders Fogh Rasmussen skrev sin meget omtalte kronik fra 2006, hvori han præsenterede sin version af en optimal dansk model for religion i kølvandet på Muhammedkrisen, rejste det en række spørgsmål om synet på religion i det danske samfund i dag (Lodberg 2007). Men det var en specifik reference i kronikken, som kom til at danne baggrund for udviklingen af det forskningsprojekt, som ligger bag denne artikel. Anders Fogh Rasmussen refererede i sin kronik til Luther som et centralt element i den model for religion og samfund, han opstillede. I forlængelse heraf ønskede jeg at finde frem til, hvor udbredt en sådan henvisningspraksis er i den danske offentlige debat, og hvilke tendenser der tegner sig, når man analyserer de indlæg i den offentlige debat, som refererer til Luther eller noget luthersk. ${ }^{1}$ I artiklen her vil jeg lægge særlig vægt på spørgsmålet om, hvorvidt man kan pege på dannelsen af bestemte normative diskurser i de tekster, der benytter henvisninger til Luther eller noget luthersk. I samme forbindelse vil jeg spørge, om disse referencer indgår i konstruktionen af en positiv egen-identitet via modstillingen til en 'kættersk' position, som fremstilles som destruktiv og falsk.

\section{At skabe sig selv ved at skabe 'den anden' - othering og identitetsgrammatik}

I denne artikel vil jeg bruge begrebet 'kætteri' i forlængelse af brugen af begrebet til analyse af fænomener uden for en specifik religiøs kontekst. ${ }^{2}$ Jacques Berlinerblau (2001, 329) betegner denne udvikling som en 'sekularisering af kætterbegrebet'. Analysen vil tage udgangspunkt i denne sekularisering af kætterbegrebet, idet jeg vil fokusere på, hvordan de generelle mekanismer bag identitetskonstruktion og 'othering' figurerer i materialet. Der er således tale om en bred brug af begrebet 'kætter', der har at gøre med konstruktionen af både en legitim og gavnlig egen-identitet og en illegitim og samfundsfarlig mod-identitet. ${ }^{3}$

Berlinerblau præsenterer et overblik over forskningsudviklingen inden for brugen af begrebet kætteri og en række grundlæggende overvejelser over brugen af begrebet, herunder at kætteribegrebet altid skal ses som relationelt, dvs. som en konstruktion, der er en central del af konstruktionen af et 'vi' over for 'dem'. Samtidig gør Berlinerblau sig til fortaler for, at kætterfænomenet skal studeres synkront og diakront med et

1 Dele af analysen af dette materiale er tidligere udgivet i Nielsen 2011, hvor der også kan findes yderligere oplysninger om forskningsprojektet om repræsentationer af Luther i en nutidig kontekst.

2 Jf. fx Howard Beckers sociologiske studier af outsidere og de mekanismer, der er i spil, når nogle markeres som uden for det normale samfund (Becker 2005 [1983]).

3 Dette brede begreb om kættere kan sammenlignes med det begreb, middelalderhistorikeren Brian McGuire bruger, når han i et indlæg i KD (21. sept. 2012: “Dovenskab er ikke sjovt længere”) mener, at de arbejdssky er vor tids kættere. 
komparativt sigte (ibid., 333). I forlængelse heraf rejser spørgsmålet sig, om det overhovedet er muligt at tale om kætteri i en moderne/senmoderne kontekst, eller om moderniteten har gjort individuel normafvigelse til et ideal i sig selv, så det ikke længere giver mening at tale om kætteri, der jo netop defineres som et normbrud. Samtidig er der i det senmoderne samfund ikke længere i samme grad hegemoniske monopolinstitutioner, der som $\mathrm{fx}$ middelalderkirken kan siges at repræsentere og opretholde en alment accepteret norm, altså en slags ortodoksi. Men som det vil fremgå af denne artikel, kan andre institutioner træde i stedet for kirken i identifikationen og stigmatiseringen af grupper eller individer, som anses for at være uden for samfundet eller destruktive for samfundets optimale udvikling. Her vil jeg navnlig komme ind på mediernes rolle i en sådan udvikling. Der kan naturligvis ikke umiddelbart trækkes en linje mellem dynamikker i middelalderkirken og i moderne medier. Ikke desto mindre vil jeg mene, at det er muligt at argumentere for, at moderne medier netop udgør en sådan kontekst i samfundet i dag. Hvad jeg påstår her er, at medierne, bl.a. i form af avisernes udvælgelse af indlæg og læserbreve, kan ses som institutioner, der understøtter de generelle mekanismer der ligger til grund for konstruktionen af kættere i en moderne sammenhæng.

Også Berlinerblau fremhæver, at der til trods for de kulturelle og samfundsmæssige forandringer fra en middelalderlig og tidlig moderne periode til i dag til stadighed er mekanismer på spil, som kan beskrives som kætteri, dvs. som konstruktioner af det heterodokse i relation til det ortodokse. I sin beskrivelse af den historiske forandring nævner han, at han er inspireret af Pierre Bourdieu og beskriver i forlængelse heraf denne overgang fra en "unquestioned and unified cultural 'tradition'" til en situation, hvor der stilles spørgsmål, og hvor der er en mængde udfordringer til enhver ortodoksi (ibid., 346). Disse udfordringer er netop med til at øge ortodoksiens kamp for at hævde sin magtposition. Det er, når situationen skifter fra noget 'naturligt' til noget, der bliver problematiseret, at kampen om at være 'sandhed' over for 'løgn' bliver relevant og intens.

Berlinerblaus brede kætterbegreb kan nu tænkes sammen med det begreb om identitet, som Gerd Baumann har formuleret; hermed får man en god kontekst, hvis man vil analysere, hvordan identitet kan skabes, idet en person eller en gruppe afgrænser sig over for andre. Gerd Baumann har nemlig i Grammars of Identity/Alterity fra 2005 givet et interessant bud på en strukturalistisk tilgang til spørgsmålet om identitet og 'othering', det at skabe sig selv ved at skabe den anden: "I divide the words 'selfing/ othering' by nothing more than a slash because they describe two faces of the same process" (Baumann 2005, 19). Han benytter begrebet 'identitetsgrammatik' til at beskrive denne proces, idet han med 'grammatik' forstår et sæt af regler, i dette tilfælde altså regler for, hvornår nogen er inkluderede eller ekskluderede. Baumann opstiller tre grundlæggende strukturer: orientalisering, segmentering og inklusion Med orientalisering mener han en udvidet binær 'othering', hvor man både tildeler 'den anden' positive og negative kendetegn, som man så spejler sig i (ibid., 19ff). Segmentering derimod opdeler sig selv og 'de andre' i en pyramidestruktur, hvor det bliver kontek- 
sten, der er afgørende for, hvornår 'vi' er 'vi'. Baumann bruger Evans-Pritchards studier af Nuer-folket som eksempel. Hvor en Nuer i nogle situationer er et 'vi,' der danner en meget lille enhed over for en fjende, så kan andre kontekster omforme denne tidligere fjende til en del af et 'vi' over for en større fælles trussel (ibid., 21). Baumann trækker også paralleller til nutidige eksempler som fx borgeres identifikation med en by, en region eller en nationalstat, samt til den logik, if. hvilken man beslutter, hvem man holder med til sportsbegivenheder. Den tredje struktur, inklusion, henter ligeledes inspiration fra antropologien, i dette tilfælde ved inddragelse af Louis Dumonts studier af indiske kastesystemer. Denne struktur inkluderer et universaliserende perspektiv i sin selfing/othering-dynamik, idet den hævder, at 'den anden' faktisk egentlig ikke er en rigtig 'anden', men tilhører 'os' på et højere niveau af identitetskonstruktionen. I dette tilfælde vil alle ultimativt være en del af 'vores' system. Med en sådan betragtning indordnes og underordnes den 'anden' i ens egen identitetsramme, og gør dermed 'den anden' ikke til en ydre fjende, men til en byggesten i ens eget identitetshierarki.

Sådanne identitetsgrammatikker indeholder et stort konfliktpotentiale og er knyttet til spørgsmål om magt og kontrol. Det at skabe sig selv via konstruktionen af en anden er en magthandling, der tjener til at placere den anden i en situation, som er styret af 'os'. 'De andre' knyttes til 'vores' meningssystem og indtager en rolle, hvor reglerne for deres identitet bestemmes af 'os'. Dette understreges også af Baumann med hans vægtlægning på, hvordan konflikt spiller ind i identitetsgrammatikker . I denne sammenhæng inddrager han også den mest ekstreme form for 'othering': benægtelsen af den andens ret til eksistens (Baumann 2005, 47). Baumann understreger, at alle tre grammatikker for selfing/othering kan være i spil samtidig, og at der således er tale om et arsenal af dynamikker, som et individ eller en gruppe kan trække på i konflikter om identitet.

Grunden til, at jeg her i artiklen vil inddrage Berlinerblaus perspektiver er, at jeg dermed kan vise, at der foregår en selfing/othering-proces i den danske, offentlige debat om Luther; det sker nemlig, når parterne i debatten om Luther gør hinanden til kættere med blik for, at der er sket en forandring i retning af en større pluralitet af konkurrerende 'ortodoksier' og et brud på den 'naturlige ortodoksi'. Og med tilføjelse af min påstand om, at medierne til dels overtager den institutionelle ramme omkring markering af 'in-groups' og 'out-groups' i den moderne og senmoderne kontekst, danner disse positioner baggrunden for en analyse af identitetskonstruktion og identifikation af 'illegitime andre'.

\section{Analyse af Luther/luthersk i den danske offentlige debat}

Nedenstående analyse er som sagt en del af mit tidligere forskningsprojekt, der tog udgangspunkt i en afdækning af brugen af Luther/luthersk i debatten i danske aviser fra 2001-2010. I den indledende fase analyserede jeg ti danske, landsdækkende avisers debatsektioner, inklusive interviews, med vægt på læserbreve og kronikker, inddraget 
via Infomedia. Den første sortering af materialet viste dels, hvor ofte ordene 'Luther' og 'luthersk' optrådte om året i disse udvalgte aviser, dels om der var bestemte aviser, hvor der over en kort periode var sket en signifikant udvikling. I årene 2000-2001 skete noget med mængden af referencer til Luther/luthersk i særligt to danske aviser: Politiken (Pol) og Jyllandsposten (JP). Her skete der en signifikant stigning i begge aviser. Jyllands-Posten gik fra at have relevante henvisninger i 0,35 \% af indlæggene i 2000 til 0,65\% i 2001 (fra 34 til 70 cases) og Politiken gik fra 0,34 \% til 0,80\% (fra 26 til 62 cases). Disse tal peger på to indledende konklusioner: For det første, at sådanne henvisninger ikke i sig selv er et dominerende fænomen i indlæggene i aviserne, og for det andet, at der skete en relativt stor stigning i begge aviser i perioden. Stigningen var i sig selv en nærliggende anledning til at studere disse indlæg i disse to aviser nærmere. Materialet, som ligger til grund for analyserne her i artiklen, dækker således kun disse to aviser i den pågældende periode; men den indledende afdækning af materialet indikerede dog, at repræsentationer af Luther i den danske debat er et gennemgående fænomen i perioden fra 2001-2010.

Detailstudiet af Politiken og Jyllandsposten 2000-2001 indebar også delanalyser af forfatternes baggrund mht. deres køn og professionelle baggrund, hvor det var muligt. Det viste sig, at der var en overvægt af forfattere, der havde en tilknytning til teologi og kirke; samtidigt var der også en forskel på avisernes profil i denne sammenhæng. I Jyllandsposten var det mellem 40-45 \%, i Politiken 15-20 \%, der direkte var tilknyttet teologiske eller kirkelige grupperinger eller institutioner. Politikere optrådte også i stort nok tal til, at der kunne siges noget om tendensen her: I Politiken var der tale om 3-6 $\%$, i Jyllandsposten 8-17 \%. Med hensyn til kønsaspektet havde 13,4 \% af bidragene en kvindelig forfatter. ${ }^{4}$ Man kunne således i udgangspunktet sige, at der var tale om en henvisningspraksis, som i høj grad, men ikke udelukkende, var baseret på mandlige skribenter med en tilknytning til kirke og teologi, men at henvisningspraksissen ikke udelukkende kom fra forfattere med en sådan profil. Dette peger på et tema, som jeg ikke vil udfolde yderligere her, nemlig præsters rolle i den offentlige debat i Danmark. ${ }^{5}$

Undersøgelsen fokuserede primært på at identificere hovedpositioner i brugen af Luther/luthersk inden for materialet. Samtidigt viste undersøgelsen at de forskellige positioner netop grupperer sig i forhold til hinanden i en proces der indebar en 'kætterstempling' af 'de andre'. Denne identifikation af diskursgrupperinger i materialet knyttede sig derfor til spørgsmålet om identitet og selfing/othering. Analysen af diskursgrupperingerne skete ud fra en metode udviklet af Gamson og Modigliani i deres arbejde med holdninger til atomkraft i offentlige medier (Gamson \& Modigliani 1989). Denne tilgang indebærer, at forskeren konstruerer en tekst, som er en samling af udsagn fundet i teksterne ud fra bestemte temaer eller tendenser. Denne konstruerede tekst er

4 For en generel præsentation og diskussion af kønsmønstre i medierne, se Byerly \& Ross 2006; Carlsson, ed., 1993.

5 I stedet vil jeg henvise til Henrik Reintoft Christensens ph.d.-afhandling, der kommer ind på dette emne (Christensen 2010). 
altså at opfatte som en slags 'idealtekst', kaldet en 'diskurspakke', som danner baggrund for en kodning af hele materialet. Kodningen af materialet foregår ved en gennemlæsning af materialet, hvor bestemte ord markeres, og derefter udføres der en statistik over, hvor mange indlæg der falder inden for de forskellige temaer. I dette tilfælde kodede jeg efter fire hovedtemaer, som bliver præsenteret nedenfor, for at kunne formulere diskurspakkerne. Målet var at finde frem til, i hvor høj grad disse pakker optræder i de to aviser, og om der er bestemte tendenser, der kan være med til at forklare den stigning, der sker i begge aviser i perioden.

Temaer og tendenser

De fire hovedtemaer, som jeg fandt i materialet, var: (1) folkekirken, (2) islam og indvandring, (3) grundlovens §4, og (4) Søren Krarup. Figur 1 viser udviklingen af temaer inden for de undersøgte aviser i perioden 2000-2001.

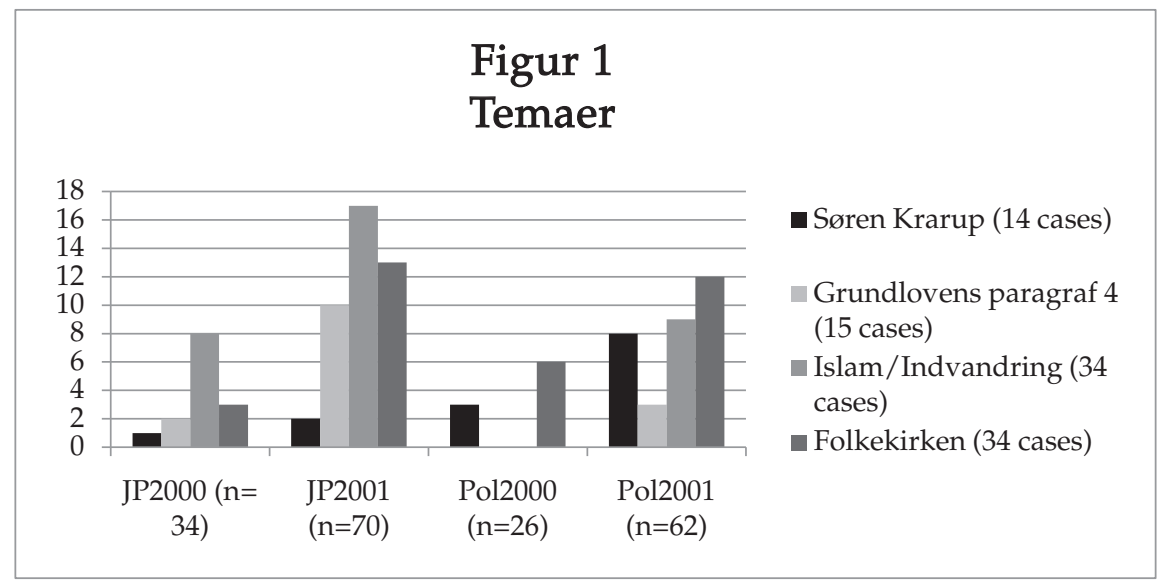

Denne oversigt giver allerede en indikation af centrale tendenser i materialet, som både kan kaste lys over, hvorfor der skete en stigning i henvisninger til Luthersk/luthersk, og som kan lede videre ind i en mere detaljeret undersøgelse af, hvad disse tilfælde handlede om. I begge aviser i begge år skete der en stigning i de temaer, som henvisningerne knyttede sig til. Dette peger på, at det drejede sig om en almen debat om nogle specifikke emner, som så at sige trak Luther/luthersk med; Luther selv optræder derimod ikke som selvstændigt tema. Disse temaer kan ses i forlængelse af, hvordan der netop i denne periode var en generelt øget fokus på nogle af de temaer, som også berøres i de indlæg, der refererer til Luther/luthersk. Fx indvandring af muslimer til Danmark, den såkaldte værdikamp, og den måde hvorpå disse diskussioner blev inddraget i valgkampen i 2001. Alle disse emner knyttede sig på forskellig vis til et over- 
ordnet tema, nemlig diskussioner om dansk kultur og samfund og om, hvordan udviklingen af det danske samfund skulle være. ${ }^{6}$

\section{Luther i sammenhæng: 'diskurspakker'}

På baggrund af indlæggenes temaer og indhold blev der konstrueret tre diskurspakker, som igen lå til grund for kodningen af materialet. Dette skete som nævnt ud fra Gamson og Modiglianis metode, udviklet i forbindelse med deres analyser af forskellige diskurser om atomkraft i en offentlig kontekst. Denne tilgang indebærer, at diskurserne identificeres ud fra forskerens konstruktion af sådanne pakker. Forskeren konstruerer således en sammenhæng mellem bidrag, der ikke nødvendigvis kommer fra forfattere, som er organiseret i fælles institutionelle strukturer eller på anden vis forbundne, men som har en tematisk sammenhæng. Teksten i en diskurspakke er som nævnt en konstruktion foretaget af forskeren, en idealtekst, som ikke findes i denne form i de konkrete tekster, men som bruges som samlende identifikationspunkt for positioner i materialet. Der er i ethvert materiale mange andre måder at inddele og kode materialet på, som så ville have givet andre perspektiver på samme data. Ud fra den vinkel, jeg valgte at se på materialet ud fra, fremgik det, at der var et overordnet tema, som blev taget op i en lang række indlæg, nemlig spørgsmålet om en sammenhæng mellem Luther/luthersk på den ene side og det danske samfund på den anden. Som nævnt ovenfor blev det sat ind i en kontekst af debat om dansk kultur og samfund generelt; men henvisninger til Luther/luthersk syntes at pege på, at det ville være relevant at se nærmere på spørgsmålet om, hvordan sammenhængen mellem dansk kultur og Luther/luthersk blev repræsenteret i indlæggene, idet der her er en klar identitetsproblematik i spil. Dette dannede baggrund for konstruktionen af tre pakker: Pakke 1 - stærk sammenhæng, Pakke 2 - ingen sammenhæng, Pakke 3 - moderat sammenhæng.

Kodningen af materialet i de tre diskurspakker viste, at ud af 192 tekster tilhørte 104 en af de tre pakker. Det vil sige, at 88 tekster falder uden for analysen nedenfor, men kort kan det siges, at selvom der er stor spredning inden for 88 tekster, så peger min analyse af dem på, at det primært er tekster, der refererer enten til institutioner, hvor luthersk indgår i navnet, eller er eksempler på, hvordan Luther/luthersk indgår som generel kulturel ressource, fx i relation til brugen af citater af Luther.

Efter præsentationen af de tre pakker vil jeg fremhæve centrale mønstre i materialet. Dernæst vil jeg fokusere på spørgsmålet om selfing/othering i relation til brugen af Luther/luthersk og knytte identifikationen af diskurspakkerne til spørgsmålet om kætteri i en moderne mediebåret kontekst. Særligt Pakke 1 og 2 udgør et godt eksem-

6 For baggrund om valget i 2001 i relation til diskussionen om især indvandring, se Qvortrup 2002; SkidmoreHess 2003; Carle 2006; Klausen 2009. For en præsentation af debatten om religiøse mindretal i Danmark og særligt muslimer, se Kühle 2001; Jacobsen 2009. For en række perspektiver, der knytter spørgsmål om identitet og religion til en diskussion af de ændringer, globalisering har medført i forhold til dette, se Hvithamar, Warburg \& Jacobsen, eds., 2009. 
pel på, at en del af præsentationen af en egen-identitet som sand og konstruktiv også indeholder stigmatiseringer af andre grupper som destruktive og kætterske.

Stærk sammenhæng - Pakke 1:

Danmark er et kristent land. Dette er udtrykt klart i Grundlovens §4: “Den evangelisk-lutherske kirke er den danske folkekirke og understøttes som sådan af staten." Der er nogle, der mener, at dette skal ændres, fordi de mener, at det ikke er i overensstemmelse med Menneskerettighedskonventionen. Men internationale konventioner skal ikke diktere, hvordan vi indretter vores samfund her i Danmark. Vi har allerede religionsfrihed i Danmark, baseret netop i vores lutherske arv, og alle trossamfund kan frit praktisere deres religion inden for lovens rammer. Disse tanker kan ses overalt i vores samfund, fx i vores skoler. Staten er forpligtet på at beskytte det danske samfunds værdier. Men disse værdier er truede i disse år på grund af indvandring af muslimske grupper. I Danmark har vi en forståelse af nødvendigheden af adskillelsen af religion og politik. Men muslimer har som mål at erstatte det demokratiske system med et religiøst styre. Vi har ikke noget udestående med muslimer som sådan; men de må acceptere, at Danmark er et kristent land. Og selvom det måske er muligt for nogle muslimer at tilegne sig danske værdier, er Islam i sig selv i fuldstændig modsætning til den danske måde at leve på og tænke på. Kun meget naive mennesker kan benægte dette faktum, og ved at benægte det bidrager de til ødelæggelsen af Danmark.

Ingen sammenhæng - Pakke 2:

Danmark er et moderne samfund bygget på demokratiske idealer. Det er et samfund, der i dag endelig er ved at blive multikulturelt, og som sådan skal det være et fuldt sekulariseret samfund. Derfor skal den danske lovgivning være i overensstemmelse med internationale normer, såsom for eksempel Menneskerettighedskonventionen. Danmark har af historiske grunde givet en særstilling til ét religiøst samfund: den evangelisk-lutherske kirke (Folkekirken); men det er på høje tid med en forandring. Først og fremmest er de lutherske værdier helt uforenelige med det moderne samfund - bare se på Luthers syn på jøder eller hans syn på kvinder. De, der i dagens Danmark citerer Luther som et eksempel, bør overveje nogle af de ting, han sagde, mere omhyggeligt. Kirke og stat skal adskilles for at opnå fuldstændig religiøs ligestilling for alle. Religionsfrihed under den nuværende model er ikke nok. Grundlovens §4 skal ændres, da den er i opposition til de grundlæggende frihedsrettigheder for den enkelte borger. Alle trossamfund skal have samme rettigheder, og staten bør ikke give særbehandling til nogen af dem. 
Moderat Sammenhæng - Pakke 3:

Danmark er et land med en historisk tilknytning til kristendommen og en indflydelsesrig evangelisk-luthersk arv. Dette kan for eksempel ses af de særlige forhold for Folkekirken i henhold til Grundlovens $\S 4$, hvor den evangelisklutherske kirke er angivet som den danske folkekirke (Folkekirken) og understøttes som sådan af staten. Denne særstatus skyldes, at flertallet af danskere tilhørte denne kirke, da Grundloven blev skrevet. Da et stort flertal af danskerne også i dag tilhører denne kirke, er der ingen grund til at ændre situationen. Men selvfølgelig betyder det ikke, at andre religiøse traditioner ikke kan eksistere i Danmark og bidrage til det danske samfund og dansk kultur. Det vigtigste er gensidig respekt og forståelse for de forskellige traditioner og fælles respekt for, hvordan det danske samfund er i dag. Vi må se på værdierne i det danske samfund og kritisk undersøge vores egen tradition. Ikke alt i den lutherske arv er kompatibelt med dagens samfund, fx nogle af de ting, Luther skrev om mennesker af andre trosretninger. Men der er nogle centrale lutherske ideer, der stadig har værdi; disse værdier er en vigtig del af dansk kultur i dag og bør ikke afvises for letsindigt, sådan som nogle gør det.

Efter kodningen af de tre pakker kunne følgende overordnede tendenser i frekvensen af indlæg identificeres jf. Figur 2:

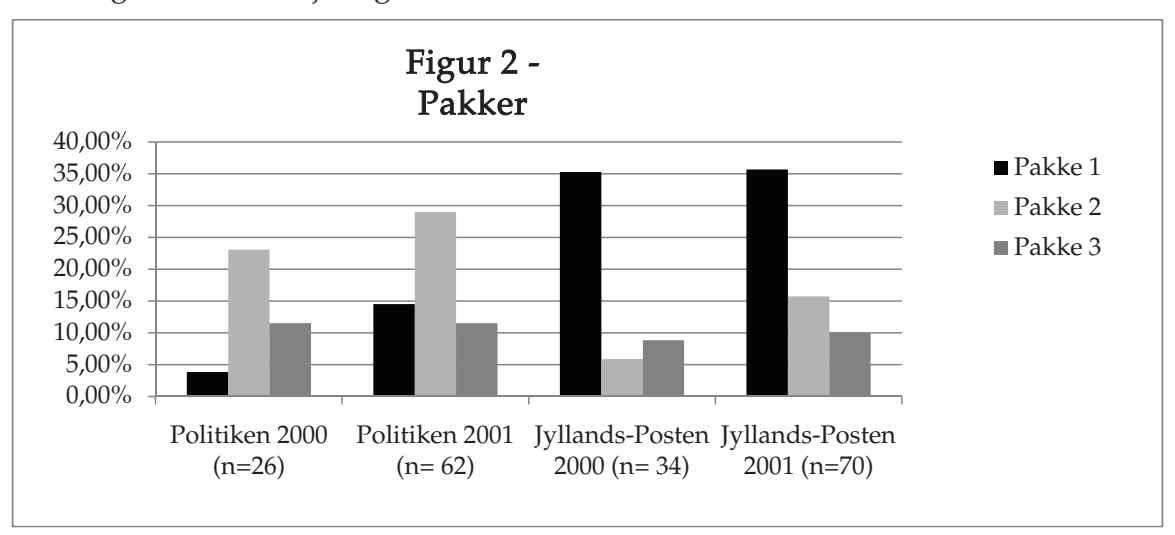

Den første centrale tendens, der kommer ud af kodningen af pakkerne er, hvordan de to aviser har meget forskellige profiler, hvad angår diskurserne. Jyllandsposten er primær eksponent for Pakke 1, Politiken for Pakke 2. De er nogenlunde lige, hvad angår Pakke 3. Men når vi ser på 2001, bliver det klart, at begge aviser her har en markant forhøjet andel af indlæg, som hører til den modsatte pakke af deres mønster. Jyllandsposten har således i 2001 en større mængde indlæg fra Pakke 2 og Politiken tilsvarende fra Pakke 1. Dette ændrer dog ikke ved, at de samtidig fastholder deres pakkeprofil og konsoliderer den i denne periode. 
Dette mønster peger på endnu en identitetsdimension i materialet, nemlig spørgsmålet om det medie, som formidler disse diskurser. Aviserne har også identiteter, de skal markere, og det er interessant at notere, hvordan begge aviser i stigende grad inddrager de modsatte synspunkter af deres traditionelle mønster for hvilke diskurspakker, de primært eksponerer. Men dette sker netop i sammenhæng med en konsolidering af deres kernepakke. Dette kan tages som et udtryk for, at de øger tilstedeværelsen af 'den anden' netop for at understrege deres 'vi'. Dette hænger sammen med et centralt emne inden for forskning i avisdebatter og medier generelt, nemlig spørgsmålet om mediets funktion i udvælgelsen af bestemt materiale, og hvordan denne udvælgelse hænger sammen med mediets identitet eller brand. Her er der tale om en bevidst strategi, som handler såvel om at markere sig med en stærk identitet, som læserne let kan identificere sig med, som om at øge salget af avisen.7 Hvis vi knytter disse mønstre i aviserne til spørgsmålet om medierne som en potentiel institutionel ramme omkring stigmatisering af bestemte grupper eller individer som 'kætterske', taler avisernes primære identiteter i forhold til de to pakker for, at aviserne som medie faktisk kan udfylde en sådan rolle og understøtte konstruktionen af positionerne over for hinanden.

\section{Luther/luthersk som identitetsmarkør}

Et fremtrædende fænomen i Pakke 1 er, hvordan noget dansk/kristent/luthersk sættes over for islam/muslimer, som en bestemt 'anden' (JP 6. feb. 2000). Dette formuleres fx som en sammenkædning af det lutherske med krav til politikerne om at markere grænser over for islam, baseret på hvordan det evangelisk-lutherske er skrevet ind i Grundlovens paragraf 4 (JP 19 mar. 2000, JP 21. okt. 2001). Her trækker nogle skribenter direkte på en religiøs 'kætter'-argumentation, idet de henviser til, at nogle lutherskevangeliske bekendelsesskrifter identificerer islam som kætteri, og at staten på grund af de tætte bånd mellem folkekirken og stat dermed er forpligtet på en bestemt afstandstagen fra islam som sådan (JP 3. sep. 2000, JP 9 jan 2001). Andre udtrykker i stedet mere generelt deres modstand mod islam uden at trække på bekendelsesskrifterne (JP 28. mar. 2000). Der er således ikke tale om en primært eller udelukkende religiøs 'anden', men en kulturel 'anden'. Dansk identitet sættes over for muslimsk identitet, idet der argumenteres for, at dansk identitet hænger sammen med en bestemt historisk udvikling, der har betydet, at det lutherske har formet en dansk model, særligt for forholdet mellem religion og politik. En skribent formulerer, hvordan denne position sætter islam op som sit modbillede:

7 Jeg vil ikke gå her gå nærmere ind i spørgsmålet om medieforskning. For litteratur med fokus på problemstillinger inden for forskning i særligt aviser, men også medier generelt, se Clegg Smith, McLeod \& Wakefield 2005; Franzosi1987; Richardson 2001. 2007. Samtidigt kunne denne analyse knyttes til overvejelser om medialiseringen af religion i Danmark, jf. Stig Hjarvards (2008) studier, som netop lægger vægt på mediernes udvikling som en institution i sig selv. 
I tider med konflikter er det altid rabiate kræfter, som får et stort ord at sige. Kristne rabiate har imidlertid ikke mulighed for at mobilisere religionen på grund af to-regimentelæren. Det har muslimer derimod. De har en god sag, for de har Koranen med sig. I mødet eller konfrontationen mellem kristendom og islam står religionerne vidt forskelligt. Kristendommen taler om næste- og fjendekærlighed, hvor islam advarer mod at tage kristne som venner. Bliver vi stående herved, er det den rene kapitulation. Men i evangeliet står tillige: Giv Gud, hvad Guds er, og kejseren, hvad kejserens er. Den sondring, som med Luther udformes til to-regimentelæren, må fastholdes over for andre religioner, da det er den, som har været vejen til samvittighedsfrihed og demokrati (JP 14. maj 2001). Her er således tale om en klassisk binær konstruktion af et luthersk 'vi' over for en muslimsk 'anden', som samtidig knytter denne modstilling til en bredere kontekst end det snævert religiøse. Det drejer sig for repræsentanterne i Pakke 1 om en grundlæggende kulturel forskel, hvor Luther/luthersk har bidraget til moderne demokrati og frihedsværdier, mens muslimer/islam ikke kan forenes med disse idealer. Der er, med Baumanns system in mente, tale om en binær spejling i dens negative version. For forfatterne bag Pakke 1-bidragene er der en særlig forbindelse mellem kristendommen i dens lutherske version og det moderne danske samfund, med værdier som demokrati og ytringsfrihed. Dette ses som særligt sikret igennem, hvad der forstås som en luthersk model til adskillelse af religion og politik, det vil sige, som bidrag til at sikre, at religiøse grupper ikke får magten til at bestemme politisk i landet; samtidigt har man en sammenhæng i samfundet baseret på den bestemte kristne tradition i dens historiske udvikling.

I Pakke 1 kan man også identificere en yderligere 'anden', der bruges til at definere sig over for, nemlig dem der går ind for et multikulturelt, dansk samfund. De beskrives negativt som 'trendsettere', der ikke ved, hvad der rører sig i befolkningen. (JP 8. aug. 2000, JP 11. nov. 2001, JP, 30. sep. 2001). Der opstilles således to 'andre', over for hvem man identificerer sig: 'den anden udefra', og 'den anden indefra'. Disse to grupper af 'andre' er forbundne, idet de 'multikulturelle' tildeles ansvaret for tilstedeværelsen af muslimer, ifølge skribenterne bag Pakke 1. I Pakke 1 finder vi også indlæg fra Søren Krarup, der som nævnt ovenfor allerede har markeret sig i materialet. Jeg vil ikke her i artiklen navngive alle bidragsydere, men da Søren Krarup spiller en så afgørende rolle i materialet, at det giver sig udtryk i, at han optræder som et selvstændigt tema, jf. de fire hovedtemaer i materialet, vil jeg i det efterfølgende inddrage ham ved navns nævnelse i en række sammenhænge.

Søren Krarup er interessant, fordi hans brug af Luther/luthersk er med til at afføde en bestemt reaktion fra visse repræsentanter for Pakke 2, som vi skal se nedenfor. Ligeledes er Søren Krarup interessant, fordi han bliver et eksempel på den kontekst, der ligger bag udviklingen fra 2000-2001, nemlig folketingsvalget i 2001, hvor han stillede op for Dansk Folkeparti. Krarup udtrykte her sit syn på sammenhængen mellem dansk kultur og Luther/luthersk over for fundamentalisme således: “At være fundamentalist er derfor også at bekende sig til en lovreligion, der som sådan er i virkelig fundamental modsætning til luthersk kristendom, for hvilken modsætningen mellem lov og 
evangelium er afgørende" (Pol 7. juni 2001). Samtidigt sættes der i denne tekst af Krarup lighedstegn mellem islam og fundamentalisme.

I Pakke 1 udtrykkes således både en religiøs modsætning mellem luthersk kristendom og islam og en kulturel modsætning som konsekvens af den religiøse mellem dansk og muslimsk. En anden forfatter i materialet udtrykker, hvordan denne forståelse indebærer en normativ model, hvor Luther/luthersk bliver adgangskrav til dansk kultur:

Vi skal ikke være enige med vore muslimske med-danskere om hverken Bibelen eller Koranen, men vi skal nødvendigvis være enige om grundloven, og det uanset om vi er muslimer eller kristne eller ingen af delene. Det kan muslimer ikke, så længe Koranens ord ubetinget går foran grundlovens. Det kan muslimer ikke, så længe de ikke skelner mellem Guds lov og menneskers love. Det kan muslimer ikke, så længe de betragter en civilisation, der ikke udtrykkelig hviler på Guds lov, som et oprør mod Gud. Der må i islam nødvendigvis komme den samme skelnen mellem de to regimenter, som Luther gennemførte for snart fem hundrede år siden i den protestantiske kristendomsforståelse (Pol 3. feb. 2001).

Man kan ikke være sand medborger, hvis ikke man har gennemgået den udvikling, som Luther er hovedrepræsentant for og som fremhæves som baggrund for en adskillelse af politik og religion, idet samfundets love altid sættes over religiøse love.

Pakke 2 repræsenterer et andet syn på sammenhængen mellem Luther/luthersk og et moderne, dansk samfund. Pakke 2 har som sit udgangspunkt, at der ikke er en sådan sammenhæng - eller hvis der har været en sådan sammenhæng engang, er den ikke længere relevant i en moderne kontekst, hvor samfundet må trække på andre ressourcer i sin fremtidige udvikling. I Pakke 2 er der mange, der taler for en adskillelse af stat og kirke som en del af en markering af et skifte til, hvad de opfatter som en moderne stat uden bånd til specifikke religiøse grupper. Dette peger på en interessant lighed mellem Pakke 1 og 2, som jeg vil diskutere yderligere nedenfor, nemlig enigheden om at politik og religion skal holdes adskilt, og at en sekulær samfundsmodel er den ideelle. Deres uenighed ligger i stedet i, hvorvidt en sådan sekularitet bedst opnås eller opretholdes igennem tilknytningen til en bestemt religiøs og historisk tradition eller ved et brud med denne tradition. Ligeledes er de enige om en fælles 'anden', nemlig 'fundamentalisme', hvilket kunne pege på, at der er flere niveauer på spil i denne othering/selfing-mekanisme. Der er således en overordnet primær kætterkategori, nemlig 'fundamentalisme', som afvises af begge parter, og som benyttes til at stigmatisere modstanderen. Her synes der at være tale om en konkurrence om at være den legitime hovedrepræsentant for, hvad det vil sige at være dansk i en moderne kontekst. Der er tale om en situation, der opfattes som en krise i det system, der i stor grad har været taget for givet indtil da, jf. Berlinerblaus overvejelser om ortodoksi/ heterodoksi i situationer, hvor den 'naturlige' orden ikke længere kan opretholdes som 'naturlig'. 
Pakke 2s repræsentanter trækker positivt på internationale normer og forbilleder som fx menneskerettighederne eller udvikling i en europæisk kontekst. Og ud fra disse autoriteter problematiseres fx forholdet mellem stat og kirke i Danmark, som fremstilles som en overtrædelse af menneskerettighederne i relation til spørgsmålet om lighed (JP 23. maj 2001). I Pakke 2 trækkes der således på andre normer, når det gælder spørgsmålet om, hvilken vej Danmark skal udvikle sig. Og ofte peges der direkte på kristendommen, og her særligt lutherske begreber, som en negativ norm, der skal brydes (JP 17. nov. 2001). Repræsentanter for pakke 2 kan beskrive repræsentanter for pakke 1 som "danske fundamentalister" (JP 18. sep. 2001). Dette peger på den dynamik, der blev nævnt ovenfor, nemlig at 'fundamentalisme' er et fælles onde for begge pakker:

Den danske frisindede kultur, som indædt hyldes, men i praksis fornægtes, er vel også nærmest opstået på trods af den lutheranske sekt, som de fleste danskere mere eller mindre bevidst tilhører. Denne kirkes stifter, en revolutionær munk, var lidt af en sammensat figur - næppe bedre end historiens øvrige store oppiskere af religiøst begrundet vanvid. Luther var en from tænker, sandhedssøger og folkehelt, men også antisemit og tilhænger af politisk undertrykkelse, med et vist også for sin samtid konservativt syn på kvinder, der vel bedst lader sig sammenligne med det, der i dag kommer til udtryk i Afghanistan - hvorfra i øvrigt en del af de nye danskere er flygtet. (JP 18. sep. 2001).

Denne tekst er et kerneeksempel på den funktion, Luther/luthersk har i Pakke 2, som en negativ norm, man skal tage afstand fra. Og det peger på, at Luther/luthersk i sig selv er blevet et symbol på Pakke 1 for repræsentanter for Pakke 2. For at overvinde Pakke 1 må man altså også underminere Luther/luthersk, og dette gøres ved at pege på, at Luther/luthersk ikke er kompatibelt med moderne værdier, idet pointen for Pakke 1 netop er, at Luther/luthersk er garant for moderne værdier i en dansk kontekst. Dette peger igen på, at sammenhængen for henvisninger til Luther/luthersk er en overordnet konflikt omkring de værdier, der skal ligge til grund for det danske samfund og at væksten i henvisninger til Luther/luthersk synes at være formet af en gensidig dynamik mellem de to stridende parter, der i en nærmest mimetisk proces begge er med til at understrege hinandens identitet, idet Pakke 2s angreb på Pakke 1 via dennes vægtlægning på Luther/luthersk er med til at bekræfte Pakke 1s ejerskab af Luther/ luthersk. Og også her spiller en enkelt person, Søren Krarup, en særlig rolle. Pakke 2 har en række eksempler på, at Søren Krarup knyttes stærkt til Luther/luthersk og udnævnes til at være repræsentant for "lutheransk fundamentalistisk sludder" (Pol 19. aug. 2000). Og angrebet på Krarup er lig med et angreb på Luther/luthersk for mange af skribenterne:

Krarup har jo et intimt fællesskab med Martin Luther, der heller ikke var begejstret for menneskerettighederne. I 1542 udgav han skriftet 'Von den Juden und ihre Lügen', hvor han bl.a. udtaler, at det er hans oprigtige forslag, at vi først brænder deres synagoger og 
hvad der ikke kan brændes dækkes med jord, at det er nødvendigt at ødelægge deres huse, at jøderne forbydes at færdes på vejene og at udrense dem for bestandig af landet (Pol 26. aug. 2000).

I Pakke 2 gøres Luther/luthersk til repræsentant for, hvad der er inkompatibelt med moderne værdier, ikke fordi forfatterne her deltager i en debat, der primært handler om Lutherreception, men fordi det handler om en konflikt om, hvilke normer der skal ligge til grund for det danske samfund. Denne del af materialet vil jeg dog ikke komme nærmere ind på her. ${ }^{8}$

Over for den polære relation mellem Pakke 1 og Pakke 2 står Pakke 3 som en alternativ position i diskussionen om, hvorvidt Luther/luthersk skal spille en rolle som positiv norm for det danske samfund. I Pakke 3 argumenteres der for, at der er en historisk sammenhæng, men at den ikke kan bruges direkte til at sætte rammerne for, hvordan udviklingen fremover skal være. Pakke 3 repræsenterer en større åbenhed end Pakke 1 over for inddragelsen af internationale tendenser og påvirkninger; men denne pakkes repræsentanter er samtidigt delvist enige med tilhængere af Pakke $1 \mathrm{i}$, at den særlige danske historiske udvikling, inklusiv en bestemt religiøs og kirkelig tradition skal opretholdes som væsentlig. Det er også i Pakke 3, man kan finde eksempler på forfattere, som repræsenterer en modstand mod brugen af Luther/luthersk hos repræsentanter for Pakke 1, men som samtidig ønsker at bruge Luther/luthersk som en positiv norm i en anden version. Dette kan fx ske igennem vægtlægning på andre fortolkninger af det lutherske materiale eller brugen af andre tekster og begreber (JP 29. okt. 2001). De kan fx beskrive Pakke 1 som repræsentant for en "stivnet lutheransk teologi" (JP 29. okt. 2001), over for hvilken de præsenterer sig selv som dynamiske og parate til at fortolke traditionen på modernitetens betingelser.

Der tegner sig således et billede af en selfing/othering i materialet, der inddrager en række konstruktioner af en 'anden' over for et 'vi', og samtidig peger det på, at konflikten ikke handler om et specifikt religiøst tema, men i stedet om en overordnet værdidebat og om at positionere sig som den rette repræsentant for, hvad det vil sige at være dansk i dag med tilknytning til spørgsmål, der trækker på en religiøs kontekst. Dette billede suppleres af, hvordan der også i forskningskredse foregår en debat om sammenhængen mellem Luther/luthersk og dansk kultur og samfund (jf. Østergaard 2003). I denne debat udtrykkes der både støtte til en sådan sammenhæng, og stærk modstand mod en sådan kobling, som det kan ses i tidsskriftet Kritik:

En mærkelig myte hjemsøger Danmark. Myten har bredt sig, netop som interessen for oplysningen og dens historie vokser. Myten lyder, at selve årsagen til europæisk oplysning

8 Citatet her ovenfor peger på et andet element i brugen af Luther/luthersk, nemlig henvisningen til konkrete skrifter af Luther. Dette sker ikke hyppigt i materialet, hvor der langt oftere er generelle henvisninger til ideer, som omtales som lutherske. Men når der henvises til konkrete skrifter, er det ofte netop skriftet om jøderne, der henvises til og som diskuteres. Denne del af materialet vil ikke her blive yderligere analyseret. 
og ytringsfrihed er ingen ringere end - Martin Luther! Ved således at rodfæste oplysningen i reformationen og protestantismen får man det til at se ud som om oplysningen er både kristen og en "dansk værdi" - ja, som noget der gror direkte ud af hjemlig, hellig muld. Det er imidlertid en grov og selvfed historieforfalskning. (Kritik 2010, 195, bagsiden).

\section{Konklusion}

Berlinerblau, Baumann og andre forskere har gjort opmærksom på forskellige sider af de underliggende dynamikker, som ofte inden for religionsområdet knyttes til historiske kætteri/ortodoksifænomener med reference til kristendommens historie. Berlinerblau pegede på, hvordan de generelle dynamikker og interessen for at analysere dem også er til stede uden for det religiøse domæne og også i en nyere kontekst under betegnelsen sekulariseringen af kætterbegrebet. Analysen af materialet her har bidraget med eksempler på kætteri i en moderne, sekulariseret kontekst: den offentlige debat i Danmark ved begyndelsen af det 21. århundrede. Referencerne til Luther/luthersk er forbundet med en religiøs kontekst, bestemte traditioner og begivenheder inden for kristendommen; men de benyttes som en del af en overordnet samfundsmæssig debat om dansk identitet. Dette er blevet knyttet til overvejelser af hvordan medier, som fx aviser, kan danne institutionel ramme omkring sådanne moderne kætterstemplingsmekanismer.

De to primære modstandere i materialet tilhører på et niveau den samme gruppe som 'danske statsborgere' forenet af deres fælles engagement i den offentlige debat. Og selvom de først og fremmest indgår i en klassisk binær relation, jf. orientalisering, i form af en negativ spejling, så danner de grundlæggende en fælles 'anden': 'fundamentalisme'. De benytter det, jeg ud fra Baumanns grammatik, vil benævne segmentering, idet de indtager et fælles niveau af selfing/othering jf. 'dansk' vs. 'fundamentalist'. Dette peger på en dynamik inden for ortodoksi/heterodoksi-diskussionen; der skal være noget, man er fælles om, før man kan optræde som hinandens 'anden'. Man skal som minimum opfattes som en person, der hører til inden for en form for fælles horisont, for at kunne fungere som den 'anden', der skaber 'vores vi'. Det fælles domæne, som alle bidrag i de tre pakker ønsker at dominere, er spørgsmålet om de værdier, der skal ligge til grund for dansk kultur. Og de fremhæver forskellige konkurrerende ressourcer, der i deres optik kan sikre en dansk kultur uden 'fundamentalisme'.

Repræsentanterne for Pakke 1 mener, at dansk kulturs frihed fra både religiøs fundamentalisme og fundamentalisme generelt er baseret på en bestemt udvikling af lutherske tanker og begreber i en dansk kontekst. Repræsentanter for Pakke 2 mener, det er omvendt; det lutherske er forbundet med en fundamentalistisk indstilling, som står i vejen for målet. Muslimer og islam optræder som en vigtig brik i debatten, men ikke primært som et aktivt, selvstændigt element; i stedet bliver de en del af den identitetsdynamik og den konflikt om 'danske værdier', hvor også Luther/luthersk indgår. 
Den funktion, som Luther/luthersk har, er som en del af denne overordnede konflikt. For Pakke 1 fungerer referencerne som en positiv norm, der bør bekræftes og opretholdes, mens der for Pakke 2 er tale om en negativ norm, der skal brydes. Men samtidig bekræfter repræsentanter for Pakke 2s angreb på Luther/luthersk, at Pakke 1 har ejerskab over Luther/luthersk. Der er eksklusionsstrategier på spil, særligt i forhold til Luther/luthersk, som forsøges udryddet ved forbindelsen til umoderne og uacceptable ideer såsom anti-semitisme af Pakke 2. Men ingen er dog så radikale, at de passer til Baumanns udelukkelsesgrammatik, hvor 'den anden' helt nægtes eksistensberettigelse. Dette kunne pege på, at en dimension af det, som Baumann benævner inklusion, er i spil, i form af, at man indtager sine forskellige positioner inden for en fælles ramme, som er det fælles offentlige debatmiljø som en legitim kampplads for de konflikter, der udspiller sig.

Ud fra de overvejelser, der er i forskningsdiskussionen af dynamikkerne bag ortodoksi/heterodoksi, kunne man således overveje, om konteksten for den stigning, vi ser i de to aviser, folketingsvalget i 2001 og i den generelle værdikamp/værdidebat, kan beskrives som en situation, hvor der er sket et brud med en 'naturlig' situation. Situationen med en dominerende, uudtalt model er således ændret til fordel for en mere usikker og åben situation, som netop derfor konstituerer sig som en oplagt kampplads for parter, der ønsker indflydelse på, hvordan den nye situation skal se ud. At der således er tale om en krise i en "unquestioned cultural tradition." Det er nok at gå for vidt at sige, at det først var i 2001, at Danmark kunne siges at skulle forholde sig til spørgsmål om multikulturalitet og om ændringer af samfundets håndtering af de institutioner, som var blevet formet som en del af den danske nationalstats udvikling. Samtidig var det dog i netop denne periode, at der kom et stort fokus på, hvordan det danske samfund skulle udvikle sig i forhold til en række af de spørgsmål, som globaliseringen stillede og fortsat stiller, særligt i forhold til migration af nye befolkningsgrupper til et samfund, der har haft en forholdsvis stor homogenitet, hvad angår fx religiøst tilhørsforhold. En række forskere har siden benyttet 'luthersk' som betegnelse for netop den forståelse af religion og samfund, som fremstilles hos fx Anders Fogh Rasmussen, men som også benyttes af mange andre i det politiske system og i den offentlige debat om religion og samfund (Berg-Sørensen 2010; Christensen 2010).

Da Anders Fogh Rasmussen i 2006 henviste til Luther som en af baggrundene for en god model for forholdet mellem religion og politik, skete denne henvisning således ikke ind i et tomrum, men ind i en allerede etableret praksis og diskurs, som indgik i en debat om det danske samfunds grundlæggende værdier. Begreber hentet fra diskussionen af selfing/othering kan være med til at identificere nogle af mekanismer, der ligger bag disse henvisninger og pege på hvilken funktion Luther har i den danske kontekst. Analyse af denne lille flig af den offentlige debat peger på, at henvisninger til Luther/luthersk i denne kontekst ofte optræder som del af et større identitetsprojekt. Og netop her spiller konstruktionen af 'kætterske andre' ind i opbygningen af 'vores' identitet i konflikten mellem konkurrerende bud på, hvad det vil sige at være 'dansk' i dag. 


\section{BIBLIOGRAFI}

Baumann, Gerd, ed.

2005 Grammars of identity and alterity: a structural approach, Berghahn Books, Oxford.

Becker, Howard S.

2005 Outsidere - studier i afvigelsessociologi, København, Hans Reitzels Forlag [Original version: Outsiders: Studies In The Sociology Of Deviance 1963]

Berg-Sørensen, Anders

2010 "The Politics of Lutheran Secularism: Reiterating Secularism in the Wake of the Cartoon Crisis", in: Lisbet Christoffersen et al., eds., Religion in the 21st Century: Challenges and Transformations, Ashgate Publishing Farnham, 207-214.

Berlinerblau, Jacques

2001 "Towards a Sociology of Heresy, Orthodoxy and Doxa", History of Religions, 40 (4), 327-351.

Byerly, Carolyn \& Karen Ross

2004 Women \& Media: A Critical Introduction, Blackwell Publishers, Malden.

Carle, Robert

2006 "Cartoon Crisis: Islam and Danish Liberalism", Society 44 (1), 80-88.

Carlsson, Ulla, ed.

1993 Nordisk forskning om kvinnor och medier, NORDICOM, Göteborg.

Christensen, Henrik. R.

2010 Religion and Authority in the Public Sphere. Representations of Religion in Scandinavian Parliaments and Media, Ph.d.-afhandling fra Det Teologiske Fakultet, Aarhus Universitet.

Clegg Smith, Katherine, Kim McLeod \& Melanie Wakefield,

2005 "Australian Letters to the Editor on Tobacco: Triggers, Rhetoric and Claims of Legitimate Voice", Qualitatively Health Research 15 (9), 1180-1198.

Fairclough, Norman

1995 Media Discourse, Hodder Education, London.

2003 Analysing Discourse: Textual Analysis for Social Research, Routledge, London.

Franzosi, Roberto

1987 "The Press as a Source of Socio-Historical Data: Issues in the Methodology of Data Collection from Newspapers," Historical Methods, 20 (1), 5-16.

Gamson, William. A. \& Andre Modigliani

1989 "Media Discourse and Public Opinion on Nuclear Power: A Constructionist Approach," American Journal of Sociology 95 (1), 1-37.

Haugen, Hans Morten

2011 "The Evangelical Lutheran Church in Denmark and the Multicultural Challenges", Politics and Religion 4, 476-502

Hjarvard, Stig, ed.

2008 "The mediatization of religion: enchantment, media and popular culture", Northern Lights: Film and Media Studies Yearbook, Intellect, Bristol.

Hvithamar, Annika, Margit Warburg \& Brian Arly Jacobsen, eds.

2009 Holy Nations and Global Identities: Civil Religion, Nationalism, and Globalisation, Brill, Leiden \& Boston.

Jacobsen, Brian A

2009 "Muslims on the Political Agenda," Nordic Journal of Religion and Society 22 (1), 15-35.

Klausen, Jytte

2009 The Cartoons that Shook the World, Yale University Press, New Haven. 
Kühle, Lene

2001 "Changes in the Religious Minority Discourse in Denmark," Tidsskrift for kirke, religion og samfunn (TKRS) 14 (2), 97-110.

Lodberg, Peter, ed.

2007 Sammenhængskraften: replikker til Fogh, Univers, Højbjerg.

Nielsen, Marie V.

2011 "Claiming Luther as a Religious Resource: Civil Religion in Conflict?", Journal of Religion in Europe, Vol. 4, (2), 300-327.

Qvortrup, Mads

2002 "The Emperor's New Clothes: The Danish General Election 20 November 2001", West European Politics 25 (2), 205-211.

Richardson, John E.

2001 “'Now Is the Time to Put an End to All This': Argumentative Discourse Theory and 'Letters to the Editor'", Discourse \& Society 12 (2), 1, 43-168.

2007 Analysing Newspapers: An Approach from Critical Discourse Analysis, Palgrave Macmillan New York.

Skidmore-Hess, Daniel

2003 "The Danish Party System and the Rise of the Right in the 2001 Parliamentary Election", International Social Science Review 78 (3-4), 89.

Stjernfelt, Frederik \& Lasse Horne Kjældgaard, eds.

2010 Kritik 195: "Protestantisme og Politik".

Østergaard, Uffe

2003 "Lutheranismen, danskheden og velfærdsstaten", in: Klaus Petersen, ed., 13 historier om den danske velfrerdsstat, Odense, Syddansk Universitetsforlag, 27-36.

Marie Vejrup Nielsen, lektor, ph.d. Religionsvidenskab, Institut for Kultur og Samfund Aarhus Universitet 